\title{
Soybean-maize intercropping feasibility under drought-prone area in East Java, Indonesia
}

\author{
ARIEF HARSONO", DIAN ADI ANGGRAENI ELISABETH"», SITI MUZAIYANAH, SALAM AGUS RIANTO \\ Indonesian Legumes and Tuber Crops Research Institute. Jl. Raya Kendalpayak Km. 8, Malang 65101, East Java, Indonesia. \\ Tel.: +62-341-8014868, Fax.: +62-341-801496, `email: rifharsono@yahoo.co.id \\ Manuscript received: 2 June 2020. Revision accepted: 25 July 2020.
}

\begin{abstract}
Harsono A, Elisabeth DAA, Muzaiyanah S, Rianto SA. 2020. Soybean-maize intercropping feasibility under drought-prone area in East Java, Indonesia. Biodiversitas 21: 3744-3754. The study aimed to determine the land productivity, economic feasibility, and soybean cultivar which is suitable for intercropped with maize in maize production center on dryland-upland in East Java, Indonesia. The study was conducted in Semanding and Merakurak Sub-districts, Tuban District, East Java, Indonesia at the end of rainy season (March-July 2019). The study used a factorial randomized block design with three replications. The first factor was planting patterns, namely: soybean intercropping with maize, maize monoculture, and soybean monoculture. The second factor was soybean cultivars, namely: Argomulyo, Dena 1, and Dega 1. The maize variety used was NK Hybrid 212. The result of study indicated that by intercropping and selecting appropriate cultivar, soybean could be developed on dryland-upland area. Soybean intercropping with plant spacing of $30 \mathrm{~cm} \times 15 \mathrm{~cm}$ and two seeds per-hill and maize in double row with plant spacing of $(40 \times 20) \mathrm{cm} \times 200 \mathrm{~cm}$ and one seed per-hill was able to produce maize seeds yield as high as maize increase LER by 1.69 , and increase farming income. Dena 1 intercropping with maize was able to provide higher benefit, economic feasibility, and land-use efficiency than Argomulyo and Dega 1, even though Dega 1 had the strongest competitiveness, and Argomulyo had the higher soybean yield.
\end{abstract}

Keywords: Dryland-upland, intercropping, maize, soybean

\section{INTRODUCTION}

Soybean is the third strategic food commodity after rice and maize in Indonesia. The average of soybean consumption per capita in Indonesia is $9 \mathrm{~kg} \mathrm{year}^{-1}$ (Riniarsi 2016). Number of population in Indonesia is 260 million (Statistics Indonesia [BPS] 2019). Therefore, the need for soybean is about 2.3 million t year ${ }^{-1}$. However, Statistics Indonesia [BPS] (2019) recorded that the domestic soybean production in 2017 only reached 538,000 t. The Indonesian government does various efforts to increase domestic soybean production in achieving national self-sufficiency, but soybean harvested area continues to decrease from year to year because it is not able to compete with maize. In the 2014-2017 period, soybean harvested area decreased from 614,000 ha to 355,000 ha, while the maize harvested area increased from 3.8 million ha to 5.5 million ha (Statistics Indonesia [BPS] 2019).

Current national soybean productivity is $1.5 \mathrm{t} \mathrm{ha}^{-1}$. Therefore, based on study of Firdaus (2015), to achieve national soybean self-sufficiency, the soybean productivity should be increased $1.6 \mathrm{t} \mathrm{ha}^{-1}$ and requires a harvest area of 1.89 million ha, so an additional harvest area of around 1.5 million ha is still needed. The increase of soybean production through expansion of planting areas can be done on suboptimal lands. One of them is in dryland-upland, which has characteristics of never being flooded, has rainfall $<2,000 \mathrm{~mm}$ year $^{-1}$ and has a number of dry months $>7$ months $\left(<100 \mathrm{~mm} \mathrm{month}^{-1}\right)$. The potential of dryland for food crop development in Indonesia reaches 3.7 million ha, mostly found in Bali and Nusa Tenggara, Sulawesi as well as Java, respectively (Mulyani et al. 2013). However, the insufficient and non-uniform distribution of rainfall on dryland results in frequent drought during the growing period triggering crop stress affected the yields reduction and even crop failure (Yazar and Ali 2017).

Food crop widely planted by farmers in DLDC is maize. Maize is one of major staple food and also a source of income for farmers (Prasanna 2012; Amegnaglo 2018; Kornher 2018). Maize productivity in dryland is relatively low, which ranges from 2.5 to $5.0 \mathrm{t} \mathrm{ha}^{-1}$ (Statistics Indonesia [BPS] 2019). Low maize productivity is caused by the erratic distribution of rain and the un-optimum maize cultivation applied by farmers. According to Machado et al. (2008), the optimal productivity of dryland where water availability is limited can be achieved through the application of cropping system that can improve water use efficiency, including intercropping. Liang et al. (2020) reported that during 2016 to 2017, cotton intercropping with mungbean in arid area of Northwest China significantly increased total land output, aboveground dry matter, nitrogen uptake, water use efficiency, nitrogen use efficiency, and economic benefit. Intercropping increases water use efficiency of crops by optimizing the soil moisture environment for crop growth (Yin et al. 2020). Based on 47 studies reported in United Kingdom and 43 studies reported in China, maize intercropping with soybean has the average LER of intercropping of $1.32 \pm 0.02$, indicating the intercropping has potential for substantial land sparing over sole crops. The average 
fertilizer $\mathrm{N}$ equivalent ratio (FNER) was $1.44 \pm 0.03$, indicating intercrops receive substantially less $\mathrm{N}$ fertilizer than sole crops for the same output. These savings of fertilizer are mainly due to the relatively high yield of maize and the lower $\mathrm{N}$ input in the intercrop compared to the input in sole maize (Xu et al. 2020).

Introduction of soybean in dryland-upland through intercropping with maize is expected to increase land productivity and farmer's income. Intercropping system has been adopted all over the world due to it can increase radiation use efficiency (RUE) and land-use efficiency (Mahallati et al. 2014; Yang et al. 2015). However, land efficiency ratio (LER) of maize intercropping with soybean rarely reaches 1.4 (Oseni 2010; Lv et al. 2014; Yu et al. 2015), so it often becomes a barrier for the development of maize-soybean intercropping. According to $\mathrm{Yu}$ et al. (2015), with good crop arrangement, the LER of maizesoybean relay cropping can reach 1.4-1.8, higher than the LER of intercropping which generally ranges from 1.2 to 1.4 .

Soybean intercropping with maize can increase land productivity (Jun-bo et al. 2018; Iqbal et al. 2019). The use of appropriate cultivars and optimal spacing in soybean intercropping is reported to be able to increase land productivity, reduce the risk of crop failure, increase yields of crops and farmer's income (Lithourgidis et al. 2011; Flores-Sanchez et al. 2013; Yang et al. 2015). The distribution of available water and water use efficiency (Rahman et al. 2017), the selection of adaptive varieties and planting pattern (Yang et al. 2015), the spatial arrangement of crops (Belel et al. 2014) as well as competitive ratio, growth improvement and light irradiance
(Yang et al. 2014) are critical aspects of intercropping on dryland-upland.

The study aims to determine the land productivity, economic feasibility, and soybean cultivar which is suitable for intercropping with maize in maize production center on dryland-upland.

\section{MATERIALS AND METHODS}

\section{Study area}

Study on soybean intercropping with maize was carried out on drought-prone area in Gesing Village of Semanding Subdistrict (1 ha) and Temandang Village of Merakurak Subdistrict (1 ha), Tuban District, East Java Province (Figure 1), Indonesia from March to July 2019. The intercropping cultivation followed the existing crop patterns applied by farmers in a year, namely maize-maize or maize-groundnut or maize-mungbean.

\section{Procedures}

The study used a factorial randomized block design with three replications. The first factor was planting patterns consisting of soybean intercropping with maize, maize monoculture, and soybean monoculture as presented in Table 1 and Figure 2. The second factor was soybean cultivars or soybean improved varieties consisting of Argomulyo (large-seeded with medium age-80 days for maturity), Dena 1 (shading tolerant seed with 78 days for maturity), and Dega 1 (large-seeded with early mature age73 days for maturity).
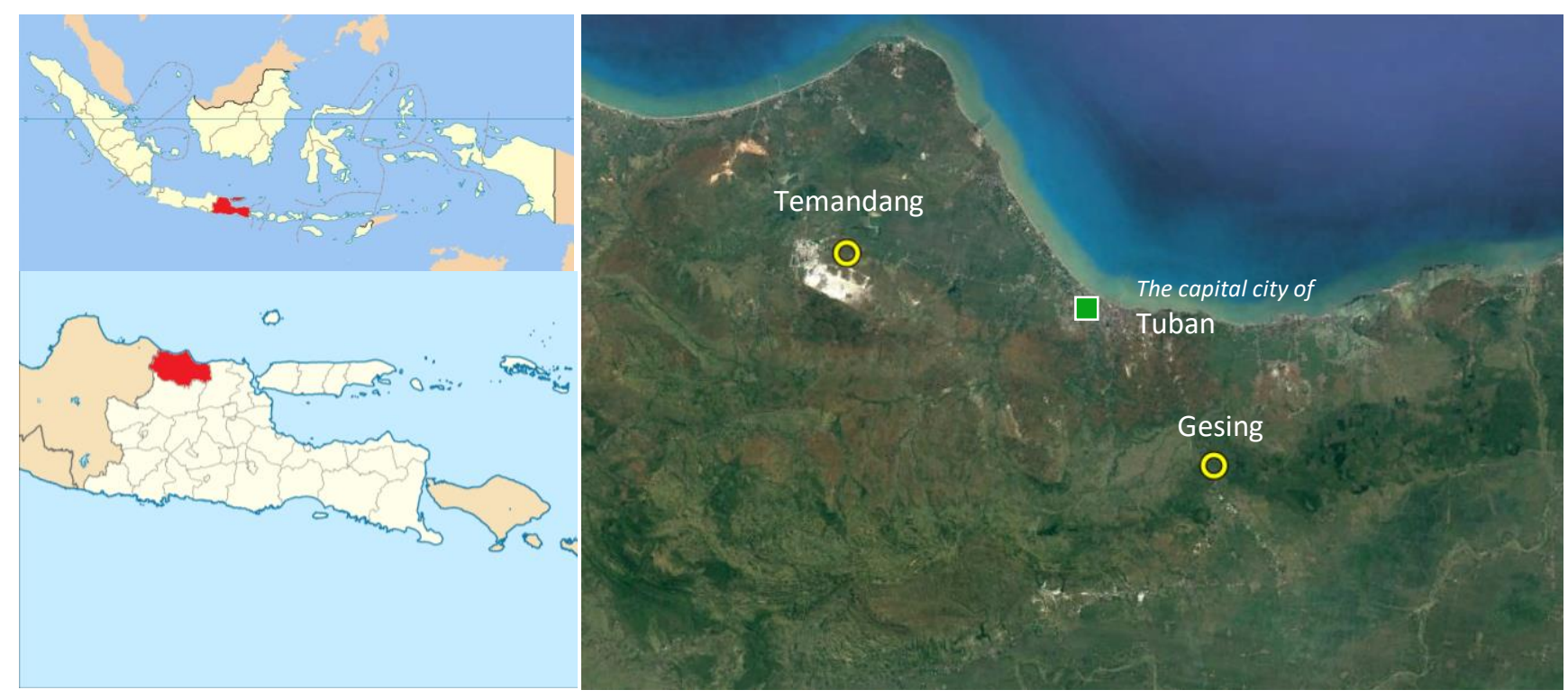

Figure 1. Study sites of Gesing Village of Semanding Subdistrict (-6 $\left.57^{\prime} 49^{\prime \prime}, 112^{\circ} 6^{\prime} 24^{\prime \prime}, 36.9 \mathrm{~m}, 2^{\circ}\right)$ and Temandang Village of Merakurak Subdistrict (-6 $\left.52^{\circ} 13^{\prime \prime}, 111^{\circ} 56^{\prime} 14^{\prime \prime}, 51.5 \mathrm{~m}, 111^{\circ}\right)$, Tuban District, East Java Province, Indonesia 


\section{Data analysis}

The technical dan economic feasibility of the cultivation technology packages for intercropping and monoculture patterns under the study was analyzed. Data collected included: chemical properties of soil before planting, distribution of rainfall, shade level of maize to soybean, yield of maize and soybean, land equivalent ratio (LER), competitive ratio (CR), and farming income. The soil was analyzed in Soil Laboratory of Indonesian Legumes and Tuber Crops Research Institute (Iletri). The shade level of maize to soybean was observed using a Digital Lux Meter of LX1330B model. The observations were conducted on three plots included on soybean canopy which was not shaded by maize, on soybean crop which was in two rows closest to the double row of maize, and on three rows of soybean crops between two double rows of maize. Each plot was observed in five spots, then the values obtained were averaged.

Land Equivalent Ratio (LER) is calculated by following equation (Liu et al. 2018):

\section{LER: LERm + LERs}

Where: LERm: Yim / Ym; LERs: Yis / Ys
LERm and LERs are, respectively, LER value of maize and LER value of soybean partially. Partial LER is not calculated based on the area of land used by each crop but based on the total area of land used in intercropping. Yim and $\mathrm{Ym}$ are, respectively, the yield of intercropping and monoculture of maize; while, Yis and Ys are, respectively, the yield of intercropping and monoculture of soybean.

Competitive ratio (CR) is the ratio of LER of each component of the crop in intercropping by calculating the proportion of each crop that has been planted in intercropping since the beginning (Yilmaz et al. 2008). The $\mathrm{CR}$ is used as indicator to evaluate the competitive ability of different commodities in intercropping (Uddin et al. 2014; Bi Tra et al. 2016). The CR is calculated by following equation (Uddin et al. 2014):

$$
\begin{aligned}
& C R=\left(Y_{i m} / Y m\right) /\left(Y_{i s} / Y_{s}\right) \times(Z i s / Z i m) \\
& C R=(\text { LERm/LERs }) \times(\text { Zis } / \text { Zim })
\end{aligned}
$$

Where: Zis: proportion of soybean crops in soybeanmaize intercropping; Zim: proportion of maize crops in soybean-maize intercropping.

Table 1. The cultivation technology packages were evaluated on dryland-upland in Tuban District, East Java, Indonesia planting season

\begin{tabular}{|c|c|c|c|}
\hline \multirow[b]{2}{*}{ Technology inputs } & \multicolumn{3}{|c|}{ Cultivation technology } \\
\hline & $\begin{array}{c}\text { Soybean intercropping } \\
\text { with maize }\end{array}$ & $\begin{array}{c}\text { Maize } \\
\text { monoculture }\end{array}$ & $\begin{array}{c}\text { Soybean } \\
\text { monoculture }\end{array}$ \\
\hline Land preparation & $\begin{array}{l}\text { In Semanding: without land preparation; } \\
\text { In Merakurak: good land preparation }\end{array}$ & $\begin{array}{l}\text { In Semanding: without land } \\
\text { preparation; } \\
\text { In Merakurak: good land } \\
\text { preparation }\end{array}$ & $\begin{array}{l}\text { In Semanding: without land } \\
\text { preparation; } \\
\text { In Merakurak: good land } \\
\text { preparation }\end{array}$ \\
\hline Drainage channels & $\begin{array}{l}\text { Made every } 4-5 \mathrm{~m} \text {; width and depth } \\
\text { about } 30 \mathrm{~cm}\end{array}$ & $\begin{array}{l}\text { Made every } 4-5 \mathrm{~m} \text {; width and } \\
\text { depth about } 30 \mathrm{~cm}\end{array}$ & $\begin{array}{l}\text { Made every } 4-5 \mathrm{~m} \text {; width and } \\
\text { depth about } 30 \mathrm{~cm}\end{array}$ \\
\hline Herbicide & $\begin{array}{l}\text { Applied 3-5 days before planting } \\
\text { soybean and maize }\end{array}$ & $\begin{array}{l}\text { Applied 3-5 days before } \\
\text { planting maize }\end{array}$ & $\begin{array}{l}\text { Applied 3-5 days before } \\
\text { planting soybean }\end{array}$ \\
\hline Planting & $\begin{array}{l}\text { Maize: } 1 \text { seed per-hill; soybean: } 2 \text { seeds } \\
\text { per-hill }\end{array}$ & 1 seed per-hill & 2 seeds per-hill \\
\hline Cultivars & $\begin{array}{l}\text { Maize: NK Hybrid } 212 \text { (by Syngenta); } \\
\text { Soybean: Argomulyo, Dena 1, and Dega } \\
1\end{array}$ & NK Hybrid 212 (by Syngenta) & $\begin{array}{l}\text { Argomulyo, Dena 1, dan Dega } \\
1\end{array}$ \\
\hline Planting method & Use manual dibbling tool & Use manual dibbling tool & Use manual dibbling tool \\
\hline Plant spacing & $\begin{array}{l}\text { Maize: double row with spacing of }(40 \mathrm{x} \\
\text { 20) } \mathrm{cm} \text { x } 200 \mathrm{~cm} \text {; soybean: } 30 \mathrm{~cm} \times 15 \mathrm{~cm}\end{array}$ & $80 \mathrm{~cm} \times 20 \mathrm{~cm}$ & $(30-40) \mathrm{cm} \times 15 \mathrm{~cm}$ \\
\hline Seed treatment & $\begin{array}{l}\text { Agrisoy } 200 \mathrm{~g} \text { per- } 50 \mathrm{~kg} \text { of soybean } \\
\text { seeds ha }{ }^{-1} \text { mixed with wet seeds just } \\
\text { before sowing }\end{array}$ & Not applied & $\begin{array}{l}\text { Agrisoy } 200 \mathrm{~g} \text { per- } 50 \mathrm{~kg} \text { of } \\
\text { seeds ha- }{ }^{-1} \text { mixed with wet seeds } \\
\text { just before sowing }\end{array}$ \\
\hline NPK fertilizer & $\begin{array}{l}\text { Maize: } 300 \mathrm{~kg} \mathrm{ha}^{-1} \mathrm{Urea}+150 \mathrm{~kg} \mathrm{ha}^{-1} \\
\text { SP36 + } 50 \mathrm{~kg} \mathrm{ha}^{-1} \mathrm{KCl} \text {; soybean: } 30 \mathrm{~kg} \mathrm{ha}^{-1} \\
\text { Urea }+60 \mathrm{~kg} \mathrm{ha}^{-1} \mathrm{SP} 36+30 \mathrm{~kg} \mathrm{ha}^{-1} \mathrm{KCl}\end{array}$ & $\begin{array}{l}300 \mathrm{~kg} \mathrm{ha}^{-1} \mathrm{Urea}+150 \mathrm{~kg} \\
\mathrm{ha}^{-1} \mathrm{SP} 36+50 \mathrm{~kg} \mathrm{ha}^{-1} \mathrm{KCl}\end{array}$ & $\begin{array}{l}50 \mathrm{~kg} \mathrm{ha}^{-1} \text { Urea }+100 \mathrm{~kg} \mathrm{ha}^{-1} \\
\text { SP36 }+50 \mathrm{~kg} \mathrm{ha}^{-1} \mathrm{KCl}\end{array}$ \\
\hline Organic fertilizer & $\begin{array}{l}\text { Maize } 1,500 \mathrm{~kg} \mathrm{ha}^{-1} \text {; soybean } 600 \mathrm{~kg} \\
\text { ha }^{-1} \text {, applied as seed hill cover }\end{array}$ & $\begin{array}{l}1,500 \mathrm{~kg} \mathrm{ha}^{-1} \text { applied as seed } \\
\text { hill cover }\end{array}$ & $\begin{array}{l}1,000 \mathrm{~kg} \mathrm{ha}^{-1} \text { applied as seed } \\
\text { hill cover }\end{array}$ \\
\hline $\begin{array}{l}\text { Pests and diseases } \\
\text { control }\end{array}$ & Sprayed with insecticides & Sprayed with insecticides & Sprayed with insecticides \\
\hline Harvesting & At physiological maturity stage & At physiological maturity stage & At physiological maturity stage \\
\hline
\end{tabular}
of 2019

Notes: NPK fertilizer for maize was applied 5-7 cm on the side of crops with the dosage of $30 \% \mathrm{~N}+100 \% \mathrm{P}_{2} \mathrm{O}_{5}+50 \% \mathrm{~K}_{2} \mathrm{O}$ at 10 days after planting and $70 \% \mathrm{~N}+50 \% \mathrm{~K}_{2} \mathrm{O}$ at 25 days after planting; NPK fertilizer for soybean was applied in a groove about 5-7 cm beside the planting line when the crops were about 10 days after planting 


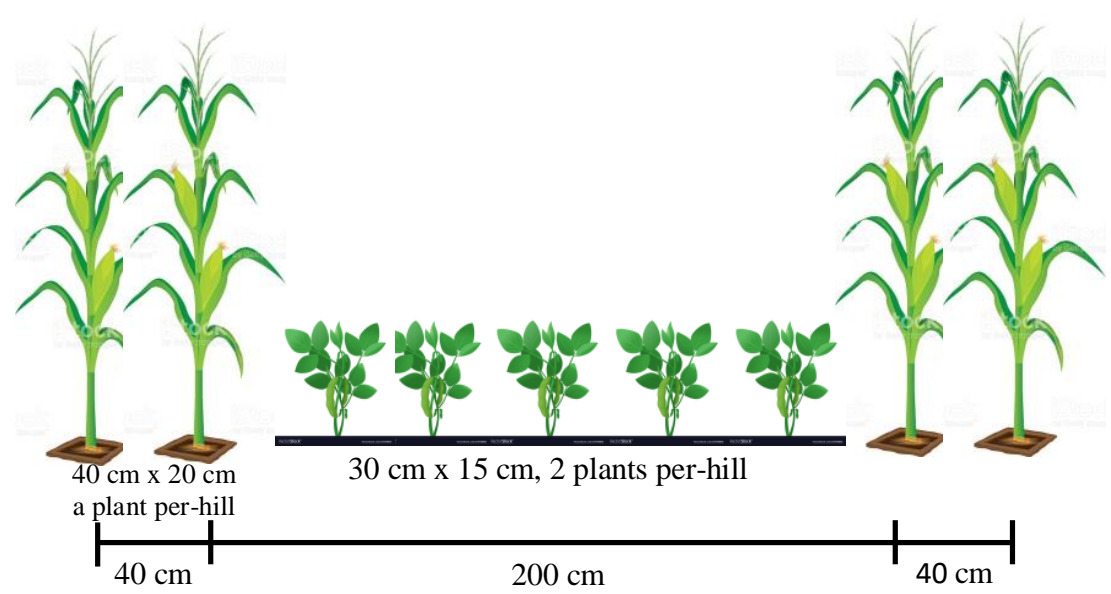

$\mathbf{A}$

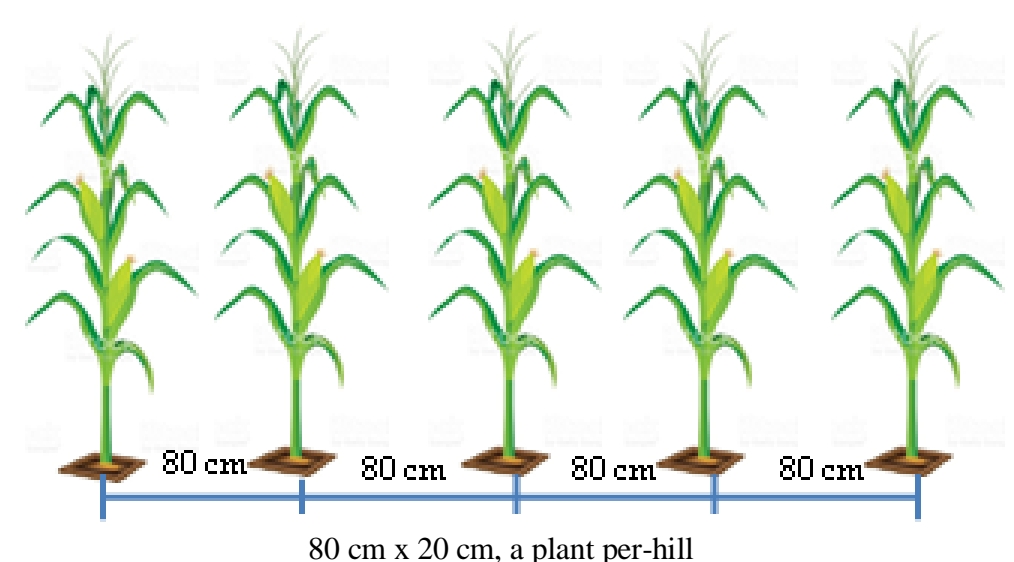

B

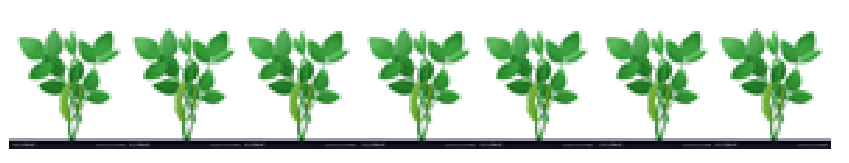

(30-40) cm x $15 \mathrm{~cm}, 2$ plants per-hill

C

Figure 2. Layout and plant spacing of soybean intercropping with maize (A), maize monoculture (B), and soybean monoculture (C), Tuban District, East Java, Indonesia, planting season of 2019

Economic feasibility of the cultivation technology packages for intercropping and monoculture employs the benefit-cost ratio (B/C ratio) approach with the following equation (Soekartawi 1995 in Istriningsih and Dewi 2015):

$$
B / C \text { ratio }=\frac{(Q \times P)-(V C+F C)}{T V C}
$$

Where: $\mathrm{B} / \mathrm{C}$ ratio: benefit-cost ratio; $\mathrm{Q}$ : production $(\mathrm{kg}$ $\mathrm{ha}^{-1}$ season ${ }^{-1}$ ); P: selling price (IDR kg ${ }^{-1}$ ); VC: variable cost (IDR) consisting of cost of production materials (seeds, organic and inorganic fertilizers, pesticides, fungicides, etc) and cost of labors; FC: fixed cost (IDR) consisting of depreciation cost of agricultural equipment or machinery; TVC: total cost (IDR ha ${ }^{-1}$ season $^{-1}$ ).

$\mathrm{B} / \mathrm{C}$ ratio is used to measure the feasibility of farming by comparing the total benefit with the total production cost (Habib et al. 2019). The analysis results of $\mathrm{B} / \mathrm{C}$ ratio are as follows: $\mathrm{B} / \mathrm{C}$ ratio $>1$, soybean-maize intercropping is profitable; $\mathrm{B} / \mathrm{C}$ ratio $=1$, soybean-maize intercropping is at the break-even point; $\mathrm{B} / \mathrm{C}$ ratio $<1$, soybean-maize intercropping is not profitable. 


\section{RESULTS AND DISCUSSION}

\section{Soil chemical properties}

The type of soil in both villages was alfisol which was located on $\mathrm{E}$ agro climate zone with a number of wet months was 3-4 months per year. The chemical properties of the soil in the two study sites were classified as alkaline with a $\mathrm{pH}$ of 8.3 . Organic $\mathrm{C}$ and total $\mathrm{N}$ contents were very low. $\mathrm{P}_{2} \mathrm{O}_{5}$ content was very high in Semanding and classified as high in Merakurak. The availability of $\mathrm{K}$ in both study sites was rather low. Ca content was very high in accordance with the property of alkaline soil. $\mathrm{Mg}$ and $\mathrm{Zn}$ content was low to moderate. $\mathrm{SO}_{4}$ and $\mathrm{Mn}$ content were low, $\mathrm{Zn}$ is low to moderate, while CEC was classified as moderate (Table 2). The soil with those chemical properties was less suitable for soybean cultivation due to besides being too alkaline the soil was also less fertile. The optimal soil $\mathrm{pH}$ for soybean crops is 5.5 to 6.5 , with minimal $\mathrm{N}$ content and organic matter was classified in moderate category (Abdurachman et al. 2013).

\section{Yield of soybean intercropping with maize}

The yields of maize for both intercropping and monoculture in Merakurak were higher than those of Semanding. The yield of maize for intercropping in each study site was not different from the monoculture because the population of maize crops that could be harvested for both intercropping and monoculture were not different (Tables 3 and 9). Soybean monoculture in Semanding and Merakurak could not be developed due to the yields of soybean were only equivalent to $42-72 \%$ and $40-42 \%$ the yields of maize monoculture. Therefore, the opportunity for developing soybean in Tuban District, particularly in production center of maize is by doing soybean intercropping with maize. Soybean intercropping with plant spacing of $30 \mathrm{~cm} \times 15 \mathrm{~cm}$ and two seeds per-hill and maize in double row with plant spacing of $(40 \times 20) \mathrm{cm} \times 200 \mathrm{~cm}$ and one seed per-hill was able to produce soybean seeds equivalent to 1.3-2.3 $\mathrm{t} \mathrm{ha}^{-1}$ of maize in Semanding, and 1.9$2.0 \mathrm{t} \mathrm{ha}^{-1}$ of maize in Merakurak, depending on the soybean cultivars planted. The intercropping was able to increase maize productivity up to $145 \%$ in Semanding and $115 \%$ in Merakurak when compared to the monoculture (Table 3). The comparative studies show that in some countries, maize productivity in intercropping is also higher than it in monoculture (Addo-Quaye et al. 2011; Mahmoudi et al. 2013; Matusso et al. 2013).

\section{Land Equivalent Ratio (LER) and Competitive Ratio (CR)}

Soybean cultivars planted determine partially the LER value of soybean and maize intercropped. Dena 1 soybean cultivar on intercropping with maize produced the highest partial LER for maize. Conversely, its partial LER for soybean was lower than other soybean cultivars of Argomulyo and Dega 1. In both Semanding and Merakurak villages, the partial LER for soybean from the cultivars of Argomulyo and Dega 1 was consistently higher than Dena 1. The LER of Dena 1 intercropped with maize was higher than the intercropped of Argomulyo and Dega 1 in Semanding and Merakurak. This is due to the CR of maize against Dena 1 was higher than the $\mathrm{CR}$ of maize against Argomulyo or Dega 1. On the other hand, the competitiveness of Dena 1 against maize in intercropping was lower than Argomulyo and Dega 1 (Table 4). The LER of maize intercropping in double row of $(40 \times 20) \mathrm{cm} \mathrm{x} 200$ $\mathrm{cm}$ with Dena 1 in Semanding and Merakurak could reach 1.69 and 1.48, respectively. This intercropping model was more efficient and productive than the maize intercropping in double row of $(20 \times 70) \mathrm{cm} \times 180 \mathrm{~cm}$ in China with the LER 1.4 (Liu et al. 2018). Du et al. (2018) reported that LER soybean intercropping with maize in China is more productive than maize monoculture with LER 1.2 to 1.6, and the yields of maize and soybean were $7.27 \mathrm{t} \mathrm{ha}^{-1}$ and $1.00 \mathrm{t} \mathrm{ha}^{-1}$, respectively. Du added that soybean and maize intercropping with double row provides the higher LER compared to the intermittent single row.

\section{Income of soybean intercropping with maize}

Soybean intercropping with maize required higher production cost than maize monoculture. However, the intercropping both in Semanding and Merakurak was able to produce higher benefits than maize monoculture (Table 5). In Semanding, maize intercropping with Argomulyo or Dena 1 cultivar was able to produce a benefit of IDR 16.4 million $\mathrm{ha}^{-1}$ or IDR 19.1 million $\mathrm{ha}^{-1}$, respectively compared to maize monoculture which only provided a benefit of IDR 13.9 million $\mathrm{ha}^{-1}$. In Merakurak, maize intercropping with Argomulyo or Dena 1 cultivar provided higher benefit than in Semanding, which was IDR 24.9 million $\mathrm{ha}^{-1}$ or IDR 25.6 million $\mathrm{h}^{-1}$ a, respectively compared to maize monoculture providing a benefit of IDR 24.5 million $\mathrm{ha}^{-1}$. The maize intercropping with Argomulyo or Dena 1 or Dega 1 cultivar was economically feasible due to the $\mathrm{B} / \mathrm{C}$ ratio was more than 1.0 both in Semanding and Merakurak. The B/C ratio of intercropping was lower than maize monoculture in two study sites. However, the total benefit obtained from intercropping was higher than maize monoculture. Besides, compared to the monoculture, the advantage of intercropping patterns was the lower risk of crop failure, particularly in the areas experiencing high drought stress.

Table 2. Soil chemical properties in two study sites, Tuban District, East Java, Indonesia, planting season of 2019

\begin{tabular}{lccc}
\hline \multirow{2}{*}{ Elements } & \multicolumn{2}{c}{ Study sites } & \multirow{2}{*}{$\begin{array}{c}\text { Adequate } \\
\text { values }\end{array}$} \\
\cline { 2 - 3 } & Semanding & Merakurak & $6.6-7.5$ \\
$\mathrm{pH} \mathrm{H} \mathrm{H}_{2} 0$ & 8.30 & 8.30 & $2.01-3.0$ \\
Organic C $(\%)$ & 0.82 & 1.27 & $0.21-0.50$ \\
$\mathrm{~N}(\%)$ & 0.10 & 0.09 & $11-15$ \\
$\mathrm{P}_{2} \mathrm{O}_{5}\left(\mathrm{ppm}^{+}\right)$ & 61.1 & 29.4 & $0.4-0.5$ \\
$\mathrm{~K}\left(\mathrm{Cmol}^{+} \mathrm{kg}^{-1}\right)$ & 0.47 & 0.38 & $6-10$ \\
$\mathrm{Ca}\left(\mathrm{Cmol}^{+} \mathrm{kg}^{-1}\right)$ & 32.94 & 19.33 & $1.1-2.0$ \\
$\mathrm{Mg}\left(\mathrm{Cmol}^{+} \mathrm{kg}^{-1}\right)$ & 0.65 & 1.86 & $17-24$ \\
$\mathrm{CEC}$ & 27.30 & 18.10 & 100 \\
$\mathrm{SO}$ & 17.90 & 25.00 & 4.5 \\
$\mathrm{Mn}(\mathrm{ppm})$ & 0.82 & 0.74 & $0.5-1.0$ \\
$\mathrm{Zn}(\mathrm{ppm})$ & 0.85 & 0.47 & \\
\hline
\end{tabular}

Notes: The soil was analyzed in Soil Laboratory of Iletri, Malang, Indonesia. ${ }^{*}$ The adequate values were according to the criteria of Indonesian Soil Research Institute (ISRI) (2019) 
Table 3. Yields of maize and soybean in soybean intercropping with maize, Tuban District, East Java, Indonesia, planting season of 2019

\begin{tabular}{|c|c|c|c|c|c|}
\hline \multirow[b]{2}{*}{ Planting patterns } & \multicolumn{4}{|c|}{ Seed yield $\left(t\right.$ ha $\left.^{-1}\right)$} & \multirow{2}{*}{$\begin{array}{c}\text { An increase against } \\
\text { maize monoculture } \\
(\%)\end{array}$} \\
\hline & Maize & Soybean & $\begin{array}{c}\text { Soybean equivalent } \\
\left.\text { to maize }{ }^{*}\right)\end{array}$ & $\begin{array}{l}\text { Total } \\
\text { yield }\end{array}$ & \\
\hline \multicolumn{6}{|l|}{ Semanding } \\
\hline Maize NK 212 monoculture & $5.488 \mathrm{~b}$ & 0 & 0 & 5.488 & 100 \\
\hline Argomulyo monoculture & 0 & $2.430 \mathrm{a}$ & 3.949 & 3.949 & 72 \\
\hline Dena 1 monoculture & 0 & $1.873 \mathrm{~b}$ & 3.044 & 3.044 & 55 \\
\hline Dega 1 monoculture & 0 & $1.419 \mathrm{c}$ & 2.306 & 2.306 & 42 \\
\hline Maize NK 212 + Argomulyo & $4.876 \mathrm{~b}$ & $1.447 \mathrm{~g}$ & 2.351 & 7.227 & 132 \\
\hline Maize NK 212 + Dena 1 & $6.297 \mathrm{~b}$ & $1.017 \mathrm{~cd}$ & 1.653 & 7.950 & 145 \\
\hline Maize NK 212 + Dega 1 & $5.635 \mathrm{~b}$ & $0.820 \mathrm{~d}$ & 1.333 & 6.968 & 127 \\
\hline \multicolumn{6}{|l|}{ Merakurak } \\
\hline Maize NK 212 monoculture & $8.877 \mathrm{a}$ & 0 & 0 & 8.877 & 100 \\
\hline Argomulyo monoculture & 0 & $2.280 \mathrm{ab}$ & 3.705 & 3.705 & 42 \\
\hline Dena 1 monoculture & 0 & $2.160 \mathrm{ab}$ & 3.510 & 3.510 & 40 \\
\hline Dega 1 monoculture & 0 & $2.280 \mathrm{ab}$ & 3.705 & 3.705 & 42 \\
\hline Maize NK 212 + Argomulyo & $7.950 \mathrm{a}$ & $1.277 \mathrm{~cd}$ & 2.075 & 10.025 & 113 \\
\hline Maize NK 212 + Dena 1 & $8.255 \mathrm{a}$ & $1.203 \mathrm{~cd}$ & 1.955 & 10.210 & 115 \\
\hline Maize NK 212 + Dega 1 & $6.317 \mathrm{~b}$ & $1.273 \mathrm{~cd}$ & 2.069 & 8.386 & 94 \\
\hline
\end{tabular}

Notes: Values in the same column that followed by the same letters show no significant difference at DMRT 5\%. Population of maize crops $100 \%$ (plant spacing of $80 \mathrm{~cm}$ x $20 \mathrm{~cm}, 2$ seeds per-hill) was $62500 \mathrm{crops} \mathrm{ha}^{-1}$ and soybean $333,333 \mathrm{crops} \mathrm{ha}^{-1}{ }^{*}{ }^{*} \mathrm{Calculated} \mathrm{based}$ on maize and soybean selling price were IDR $4000 \mathrm{~kg}^{-1}$ and IDR $6500 \mathrm{~kg}^{-1}$ of dried seeds, respectively

Table 4. Land Equivalent Ratio (LER) and Competitive Ratio (CR) of soybean intercropping with maize, Tuban District, East Java, Indonesia, planting season of 2019

\begin{tabular}{lccccc}
\hline Planting patterns & LER of maize & LER of soybean & LER & CR of maize & CR of soybean \\
\hline Semanding & & & & 1.48 & 1.32 \\
Maize NK 212 + Argomulyo & 0.89 & 0.60 & 1.69 & 1.87 & 0.76 \\
Maize NK 212 + Dena 1 & 1.15 & 0.54 & 1.60 & & 0.53 \\
Maize NK 212 + Dega 1 & 1.03 & 0.58 & & & \\
Merakurak & & & 1.58 & 1.41 & 0.63 \\
Maize NK 212 + Argomulyo & 0.89 & 0.56 & 1.48 & 1.50 & 0.67 \\
Maize NK 212 + Dena 1 & 0.93 & 0.55 & 1.27 & 1.23 & 0.89 \\
Maize NK 212 + Dega 1 & 0.71 & 0.56 & & \\
\hline
\end{tabular}

Table 5. Farming income of several soybean cultivars intercropping with maize, Tuban District, East Java, Indonesia, planting season of 2019

\begin{tabular}{|c|c|c|c|c|c|c|c|c|}
\hline \multirow{2}{*}{ Planting patterns } & \multicolumn{2}{|c|}{ Yield (t ha' $\left.{ }^{-1}\right)$} & \multirow{2}{*}{$\begin{array}{l}\text { Total revenue } \\
\left(\text { IDR } 000 \text { ha }^{-1}\right)\end{array}$} & \multicolumn{2}{|c|}{$\begin{array}{c}\text { Cost production (IDR } \\
000 \mathrm{ha}^{-1} \text { ) } \\
\end{array}$} & \multirow{2}{*}{$\begin{array}{c}\text { Total cost } \\
\left(\text { IDR } 000 \text { ha }^{-1}\right)\end{array}$} & \multirow{2}{*}{$\begin{array}{l}\text { Total benefit } \\
\left(\text { IDR } 000 \text { ha'-1) }^{-1}\right.\end{array}$} & \multirow[t]{2}{*}{$\mathrm{B} / \mathrm{C}$} \\
\hline & Maize & Soybean & & Maize & Soybean & & & \\
\hline \multicolumn{9}{|l|}{ Semanding } \\
\hline Maize NK 212 monoculture & 5.488 & 0 & 21,952 & 8,032 & 0 & 8,032 & 13,920 & 1.73 \\
\hline Argomulyo monoculture & 0 & 2.430 & 15,795 & 0 & 7,02 & 7,022 & 8,773 & 1.25 \\
\hline Dena 1 monoculture & 0 & 1.873 & $12,174.5$ & 0 & 6,802 & 6,802 & $5,372.5$ & 0.79 \\
\hline Dega 1 monoculture & 0 & 1.417 & $9,210.5$ & 0 & 6,622 & 6,622 & $2,588.5$ & 0.39 \\
\hline Maize NK 212 + Argomulyo & 4.876 & 1.447 & $28,909.5$ & 7,972 & 4,540 & 12,512 & $16,397.5$ & 1.31 \\
\hline Maize NK 212 + Dena 1 & 6.297 & 1.017 & $31,798.5$ & 8,252 & 4,400 & 12,652 & $19,146.5$ & 1.51 \\
\hline Maize NK 212 + Dega 1 & 5.635 & 0.820 & 27,870 & 8,047 & 4,180 & 12,227 & 15,643 & 1.28 \\
\hline \multicolumn{9}{|l|}{ Merakurak } \\
\hline Maize NK 212 monoculture & 8.877 & 0 & 35,508 & 10,982 & 0 & 10,982 & 24,526 & 2.23 \\
\hline Argomulyo monoculture & 0 & 2.280 & 14,820 & 0 & 6,962 & 6,962 & 7,858 & 1.13 \\
\hline Dena 1 monoculture & 0 & 2.160 & 14,040 & 0 & 6,762 & 6,762 & 7,278 & 1.08 \\
\hline Dega 1 monoculture & 0 & 2.280 & 14,820 & 0 & 6,962 & 6,962 & 7,858 & 1.13 \\
\hline Maize NK 212 + Argomulyo & 7.950 & 1.277 & $40,100.5$ & 10,607 & 4,520 & 15,127 & $24,973.5$ & 1.65 \\
\hline Maize NK 212 + Dena 1 & 8.255 & 1.203 & $40,839.5$ & 10,917 & 4,360 & 15,277 & $25,562.5$ & 1.67 \\
\hline Maize NK 212 + Dega 1 & 6.317 & 1.273 & $33,542.5$ & 10,727 & 4,380 & 15,107 & $18,435.5$ & 1.22 \\
\hline
\end{tabular}

Note: Maize and soybean selling prices were IDR $4000 \mathrm{~kg}^{-1}$ and IDR $6500 \mathrm{~kg}^{-1}$ of dried seeds, respectively 


\section{Discussion}

The yields of maize and soybean in Merakurak using both intercropping and monoculture patterns were generally higher than in Semanding. It was caused by the higher rainfall in Merakurak compared to Semanding (Figure 3). As stated in the Methodology, this study was carried out at the end of the rainy season following the existing crop pattern of maize-maize. The first maize was planted by farmers at the beginning of the rainy season in December 2018, and the second maize is planted at the end of the rainy season in March 2019 to utilize the remaining rainfall.

In Semanding, the water need for the crops is entirely dependent on rainfall because there are no pumping wells that can be used to irrigate the crops. The rainfall during soybean and maize growth was $477 \mathrm{~mm}$ and $482 \mathrm{~mm}$, respectively (Figure 3 ). The total rainfall met the water need of soybean crops, but it was still lacking for maize. The water need of maize to grow optimally ranges from 539 to $692 \mathrm{~mm}$ (Ankidawa and Vanke 2018), and at the peak of reproductive period maize requires water of 549 $\mathrm{mm}$ per day (Chuanyan and Zhongren 2007). The distribution of rainfall was also not good. During the vegetative period, the rainfall during the first 30 days reached $285 \mathrm{~mm}$ and it was excessive to meet the water needs of soybean and maize. In the first 30 days, soybean only needed water $130 \mathrm{~mm}$. In the reproductive period, the rainfall from 30 to 60 days reached $192 \mathrm{~mm}$, then from 60 days to the harvest time there was no more rainfall (Figure 3 ). The total rainfall in this reproductive period nearly meets the optimal water need of soybean which is $203 \mathrm{~mm}$ (Stansell et al. in Boote et al. 1982).

In Merakurak, the rainfall during the soybean and maize growth was $665 \mathrm{~mm}$ and $705 \mathrm{~mm}$, respectively. The rainfall was excessive to meet the water need of soybean, yet enough for maize. Therefore, vegetative period of soybean and maize crops in Merakurak was better than in Semanding as indicated by the differences in plant height and weight (Figure 4, Tables 6 and 7). However, the uneven distribution of rainfall during the plant growth was a constraint in the reproductive period. There was no rain from 60 to 80 days old of soybean and maize crops and they suffered from drought stress; whereas, during that period, both of them needed more water for the seeds filling process. So that the crops did not experience drought stress, at the age of 65 and 75 days they were given the addition of irrigation water from pump wells. There was 40 $\mathrm{mm}$ of rain at the age of 80 days, so the crops did not experience drought stress and the process of seeds filling could take place well until the physiological cooking phase of soybean seeds.

The rainfall with higher intensity and better distribution in Merakurak caused the maize crops in Merakurak to grow higher than in Semanding (Figure 4). As a result, the shade level received by soybean crops in Merakurak was higher than the shade received in Semanding (Figure 5). In Semanding, the average shade of maize crops above the canopy of soybean at the age of 40 and 60 days was 43$43 \%$ and 55-58\%, respectively. Meanwhile, in Merakurak, the average shade of maize crops was 53-59\% at the age of 40 days and 58-63\% at 60 days (Figure 5). This condition caused the lower competitiveness of soybean crops against maize in Merakurak than in Semanding. As a result, the productivity of soybean with intercropping patterns in Merakurak was lower than in Semanding (Table 3).

In China, intercropping pattern in double row with alley model for maize was better than double row intercropping because it could increase Photosynthetic Active Radiation (PAR) soybean and maize 1.42-1.93 times and 1.02-1.12 times, respectively (Liu et al. 2018). Intercropping with alley model is also able to increase the efficiency of solar radiation use and the rate of soybean crops photosynthesis. The recommended width between maize crops for the best soybean cultivation was $1.6 \mathrm{~m}-1.8 \mathrm{~m}$ and the spacing of maize was in $0.4 \mathrm{~m}$. According to Liu et al. (2017), photosynthesis rate of the upper side of soybean leaves in the intercropping with $1.8 \mathrm{~m}$ alley model could reach $80 \%$ compared to soybean monoculture. While, in intercropping with single row, the photosynthesis rate of the upper side of soybean leaves only reached $46 \%$ compared to soybean monoculture.
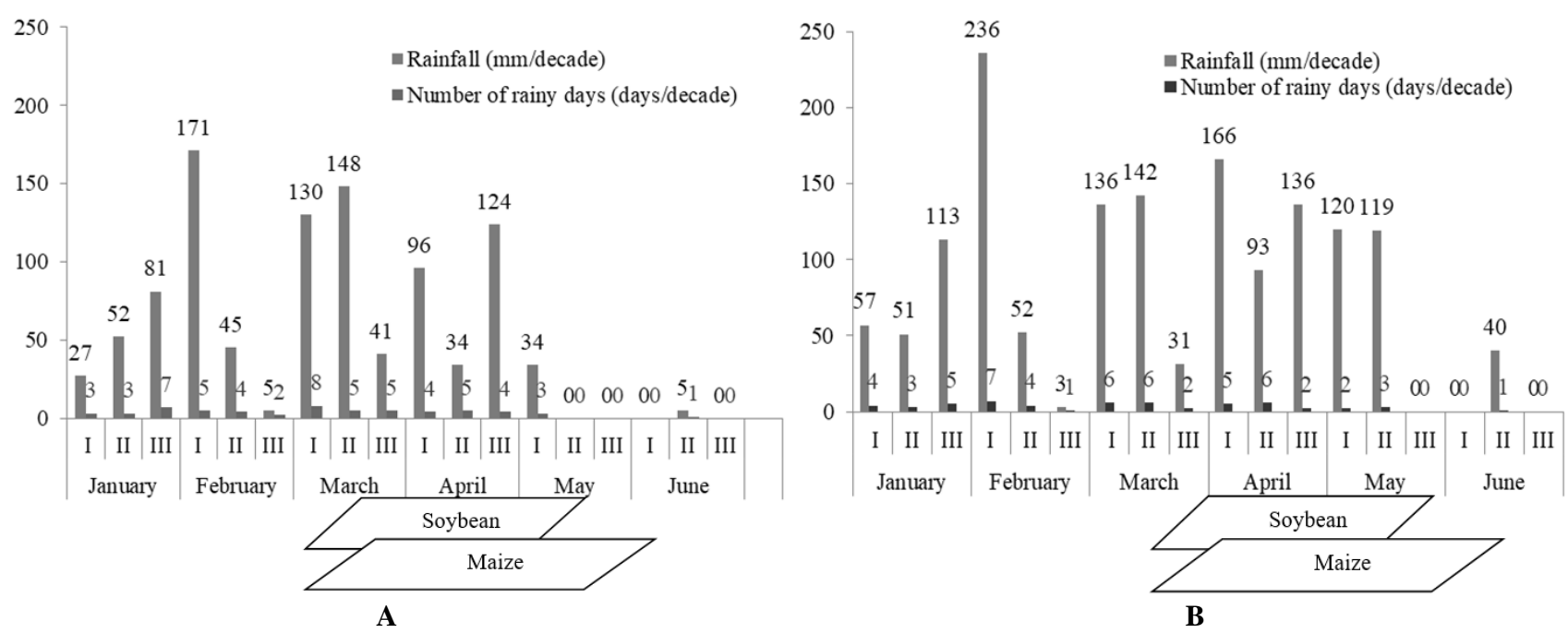

Figure 3. Distribution of rainfall and number of rainy days during crops growth in Semanding (A) and Merakurak (B), Tuban District, East Java, Indonesia, planting season of 2019 

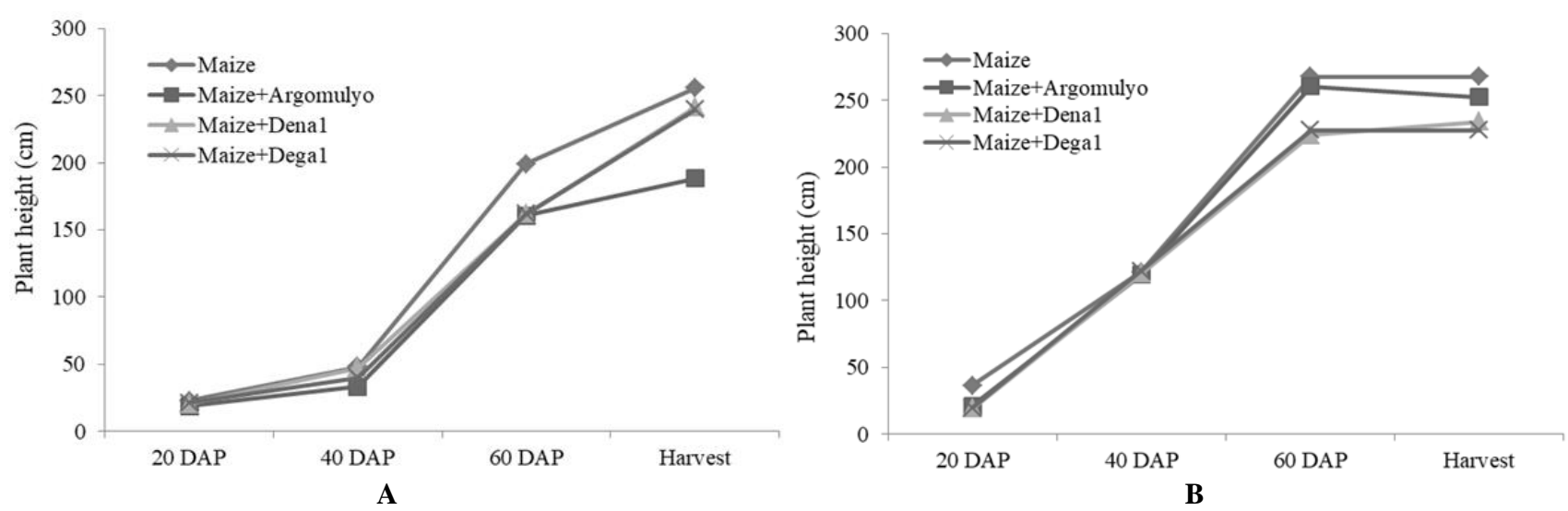

Figure 4. Plant height of maize NK 212 monoculture and intercropping with soybean cultivars of Argomulyo, Dena 1, and Dega 1 in Semanding (A) and Merakurak (B), Tuban District, East Java, Indonesia, planting season of 2019
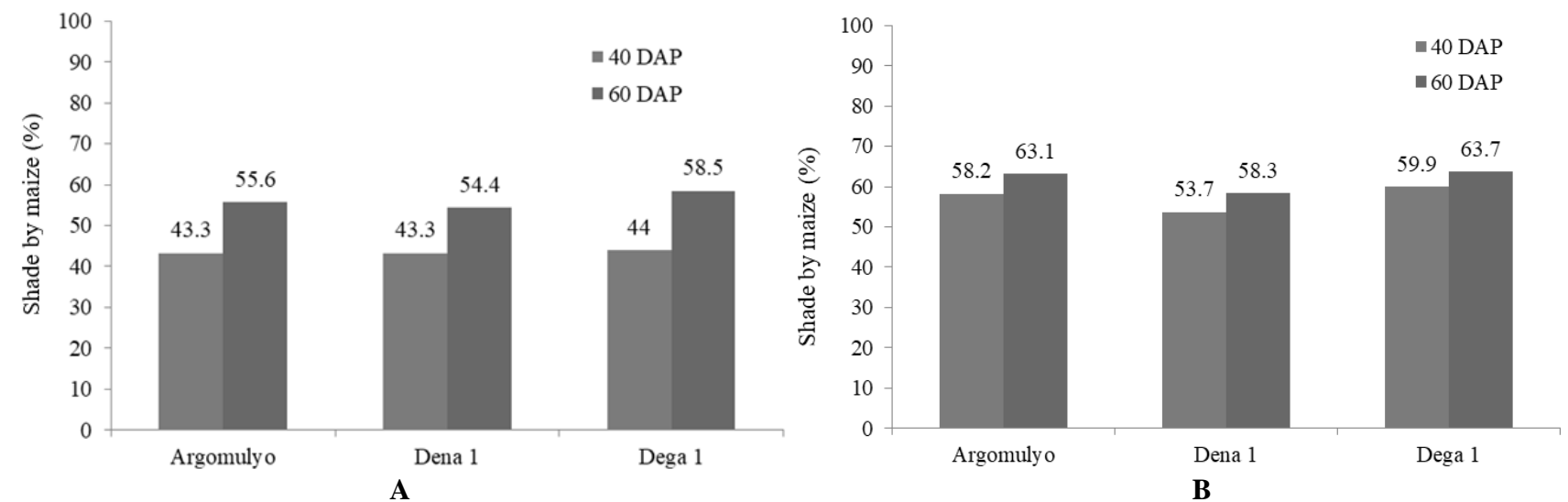

Figure 5. Shade level of maize above soybean canopy at the age of 40 and 60 days in soybean intercropping with maize NK 212 in Semanding (A) and Merakurak (B), Tuban District, East Java, Indonesia, planting season of 2019. Average intensity of solar radiation without shade experienced by soybean at the age of 40 days and 60 days was 138633 lux and 138583 lux, respectively, in Semanding and 149088 lux and 149361 lux, respectively, in Merakurak

Statistically, at the age of 20 and 40 days, plant height of soybean intercropping with maize and soybean monoculture was not significant due to the shade level effect of maize crops above soybean. However, at the harvest time, soybean intercropping grew higher than the monoculture, particularly for Dena 1 (Table 6). In general, soybean monoculture grew better than the intercropping as can be seen from the crop weight of soybean monoculture which is heavier than intercropping (Table 7). In normal conditions, the height of Argomulyo, Dena 1, and Dega 1 cultivars are $40 \mathrm{~cm}, 59 \mathrm{~cm}$, and $53 \mathrm{~cm}$, respectively (Iletri 2016).

The yields of maize monoculture and intercropping both in Semanding and Merakurak which were not different were caused by the no differences on the number of plants and the number of maize cobs that could be harvested, the number of seeds per each cob and the weight of 100 maize seeds between the two planting patterns (Table 7). Maize intercropping in double row with plant spacing of $(40 \times 20) \mathrm{cm} \times 200 \mathrm{~cm}$ and one seed per-hill was able to produce the same number of plants and the same number of maize cobs as maize monoculture with spacing of $80 \mathrm{~cm} \times 20 \mathrm{~cm}$ and one seed per-hill (Table 8). Liu et al. (2018) reported that the yield of maize intercropping with $1.8 \mathrm{~m}$ alley model could reach $90 \%$ compared to the yield of maize monoculture. The photosynthesis rate of maize intercropping with alley model was also not significantly different when compared to maize monoculture. 
Table 6. Plant height of soybean monoculture and intercropping with maize NK 212 in Semanding and Merakurak, Tuban District, East Java, Indonesia, planting season of 2019

\begin{tabular}{lcccccc}
\hline \multirow{2}{*}{ Planting patterns } & \multicolumn{3}{c}{ Plant height (cm) } \\
\cline { 2 - 6 } & \multicolumn{2}{c}{ 20 DAP } & \multicolumn{2}{c}{ 40 DAP } & \multicolumn{2}{c}{ Harvest } \\
\cline { 2 - 7 } & Monoculture & Intercropping & Monoculture & Intercropping & Monoculture & Intercropping \\
\hline Semanding & & & & & & \\
Argomulyo & $16.8 \mathrm{ef}$ & $17.9 \mathrm{de}$ & $34.9 \mathrm{c}$ & $42.1 \mathrm{a}$ & $61.3 \mathrm{~b}$ & $61.2 \mathrm{~b}$ \\
Dena 1 & $15.7 \mathrm{f}$ & $16.6 \mathrm{ef}$ & $38.1 \mathrm{abc}$ & $41.9 \mathrm{a}$ & $64.7 \mathrm{~b}$ & $69.0 \mathrm{a}$ \\
Dega 1 & $14.0 \mathrm{~g}$ & $16.1 \mathrm{f}$ & $38.2 \mathrm{abc}$ & $36.0 \mathrm{bc}$ & $53.4 \mathrm{c}$ & $64.8 \mathrm{~b}$ \\
Merakurak & & & & & \\
Argomulyo & $20.1 \mathrm{bc}$ & $19.6 \mathrm{bc}$ & $40.6 \mathrm{a}$ & $39.2 \mathrm{ab}$ & $61.0 \mathrm{~b}$ & $63.0 \mathrm{~b}$ \\
Dena 1 & $20.8 \mathrm{~b}$ & $23.0 \mathrm{a}$ & $36.2 \mathrm{bc}$ & $42.0 \mathrm{a}$ & $64.9 \mathrm{~b}$ & $69.2 \mathrm{a}$ \\
Dega 1 & $19.3 \mathrm{~cd}$ & $19.2 \mathrm{~cd}$ & $42.0 \mathrm{a}$ & $39.8 \mathrm{ab}$ & $57.0 \mathrm{c}$ & $56.8 \mathrm{c}$ \\
\hline
\end{tabular}

Notes: DAP = days after planting, Values in the same plant age columns that followed by the same letters show no significant difference at DMRT 5\%

Table 7. Crop population and yield components of maize monoculture and intercropping with soybean, Tuban District, East Java, Indonesia, planting season of 2019

\begin{tabular}{lcccc}
\hline \multirow{2}{*}{\multicolumn{1}{c}{ Planting patterns }} & \multicolumn{4}{c}{ Total dry weight per plant at 60 DAP (g) } \\
\cline { 2 - 5 } & \multicolumn{3}{c}{ Maize } & \multicolumn{2}{c}{ Soybean } \\
\cline { 2 - 5 } & Semanding & Merakurak & - & Merakurak \\
\hline Maize NK 212 monoculture & $83.09 \mathrm{bc}$ & $104.66 \mathrm{a}$ & - \\
Argomulyo monoculture & - & - & $17.64 \mathrm{ab}$ & $15.22 \mathrm{~cd}$ \\
Dena 1 monoculture & - & - & $18.52 \mathrm{a}$ & $16.86 \mathrm{abc}$ \\
Dega 1 monoculture & - & - & $16.62 \mathrm{bc}$ & $13.88 \mathrm{de}$ \\
Maize NK 212 + Argomulyo & $80.04 \mathrm{c}$ & $103.15 \mathrm{a}$ & $13.87 \mathrm{de}$ \\
Maize NK 212 + Dena 1 & $78.26 \mathrm{c}$ & $94.03 \mathrm{ab}$ & $17.30 \mathrm{ab}$ & $12.82 \mathrm{e}$ \\
Maize NK 212 + Dega 1 & $75.41 \mathrm{c}$ & 74.58 & $15.17 \mathrm{~cd}$ & $10.87 \mathrm{f}$ \\
\hline
\end{tabular}

Note: Values in the same plant (maize or soybean) columns that followed by the same letters show no significant difference at DMRT $5 \%$

The yield of soybean intercropping was lower than soybean monoculture both in Semanding and Merakurak. It was caused by the lower number of soybean crops harvested from the intercropping in both study sites when compared to the monoculture which was $72-74 \%$ and 74 $76 \%$ in Semanding and Merakurak, respectively (Table 9). In general, the number of pods and the weight of 100 seeds between monoculture and intercropping patterns were not different. Thus, it indicated that the three soybean cultivars could grow well in the shade level of $40-60 \%$, with the average solar radiation intensity was in the range of 138,600 lux to 149,300 lux.

The weight of 100 seeds of Dega 1 cultivar was higher than that of Argomulyo and Dena 1. According to Iletri (2016), the weight of 100 seeds of Dega 1, Argomulyo, and Dena 1 cultivars are $22.9 \mathrm{~g}, 16 \mathrm{~g}$, and $14.3 \mathrm{~g}$, respectively. Even though Dega 1 has heavier weight of 100 seeds, but the lower population could be harvested affected by the yield of Dega 1 that was not different from Argomulyo and Dena 1. Dega 1 is being more susceptible to the drought stress compared to Dena 1 and Argomulyo therefore it causes to the lower population of this cultivar.

\section{Technical and economic feasibility}

The LER value of soybean intercropping with maize could reach 1.48-1.69 depending on the soybean cultivars used (Table 4). The higher LER value of Dena 1 intercropping with maize was caused by the lower competitive ratio of Dena 1 against maize (Table 4), so that maize could achieve the optimal yield. This showed that from a technical perspective, the intercropping pattern of soybean with maize was more efficient and more productive in terms of land use than both maize and soybean monoculture. Even though the production cost of the intercropping was higher than both maize and soybean monoculture, but the intercropping was able to provide higher benefits (Table 5). The total benefits of soybean intercropping with maize in Semanding and Merakurak could reach IDR 19.1 million and IDR 25.5 million ha ${ }^{-1}$, respectively, meanwhile, the total benefits from maize monoculture reached IDR 13.9 million $\mathrm{ha}^{-1}$ in Semanding and IDR 24.5 million ha ${ }^{-1}$ in Merakurak. For the purpose to obtain high soybean yield in soybean intercropping with maize, it was better to use Argomulyo cultivar. However, for obtaining higher land-use efficiency and benefit as well as the higher economic feasible intercropping, Dena 1 was more suitable (Tables 3 and 4). 
Table 8. Crop population and yield components of maize monoculture and intercropping with soybean, Tuban District, East Java, Indonesia, planting season of 2019

\begin{tabular}{|c|c|c|c|c|c|}
\hline Planting patterns & $\begin{array}{l}\text { Harvested plant } \\
\left.\text { population }(\%)^{*}\right)\end{array}$ & $\begin{array}{c}\text { Number of } \\
\text { harvested maize } \\
\text { cobs }(\mathbf{x 1 0 0 0 )}\end{array}$ & $\begin{array}{c}\text { Number of } \\
\text { seeds per-cob }\end{array}$ & $\begin{array}{l}\text { Weight of } 100 \\
\text { seeds }(\mathrm{g})\end{array}$ & $\begin{array}{c}\text { Yield } \\
\left(\mathrm{t} \mathrm{ha}^{-1}\right)\end{array}$ \\
\hline \multicolumn{6}{|l|}{ Semanding } \\
\hline Maize NK 212 monoculture & $100.0 \mathrm{a}$ & $61.4 \mathrm{a}$ & $465.6 \mathrm{ab}$ & $28.4 \mathrm{a}$ & $5.488 \mathrm{~b}$ \\
\hline Maize NK 212 + Argomulyo & $94.3 \mathrm{abc}$ & $59.1 \mathrm{a}$ & $415.6 \mathrm{ab}$ & $29.3 \mathrm{a}$ & $4.876 \mathrm{~b}$ \\
\hline Maize NK 212 + Dena 1 & $88.6 \mathrm{c}$ & $57.0 \mathrm{a}$ & $382.0 \mathrm{~b}$ & $28.9 \mathrm{a}$ & $6.297 \mathrm{~b}$ \\
\hline Maize NK 212 + Dega 1 & $80.0 \mathrm{~d}$ & $47.2 \mathrm{~b}$ & $399.6 \mathrm{ab}$ & $27.6 \mathrm{a}$ & $5.635 \mathrm{~b}$ \\
\hline \multicolumn{6}{|l|}{ Merakurak } \\
\hline Maize monoculture & $100.0 \mathrm{a}$ & $62.7 \mathrm{a}$ & $465.3 \mathrm{ab}$ & $30.2 \mathrm{a}$ & $8.877 \mathrm{a}$ \\
\hline Maize NK $212+$ Argomulyo & $95.0 \mathrm{ab}$ & $64.9 \mathrm{a}$ & $464.0 \mathrm{ab}$ & $29.2 \mathrm{a}$ & $7.950 \mathrm{a}$ \\
\hline Maize NK 212 + Dena 1 & $99.3 \mathrm{a}$ & $62.9 \mathrm{a}$ & $471.3 \mathrm{ab}$ & $31.6 \mathrm{a}$ & $8.255 \mathrm{a}$ \\
\hline Maize NK 212 + Dega 1 & $90.3 \mathrm{bc}$ & $59.6 \mathrm{a}$ & $529.7 \mathrm{a}$ & $27.9 \mathrm{a}$ & $6.317 \mathrm{~b}$ \\
\hline
\end{tabular}

Notes: Values in the same column followed by the same letter show no significant difference in DMRT 5\%. $\left.{ }^{*}\right)$ Population of $100 \%$ maize crop with plant spacing of $80 \mathrm{~cm}$ x $20 \mathrm{~cm}, 2$ seeds per-hill was $62500 \mathrm{crops} \mathrm{ha}^{-1}$

Table 9. Crop population and yield components of soybean monoculture and intercropping with maize, Tuban District, East Java, Indonesia, planting season of 2019

\begin{tabular}{|c|c|c|c|c|}
\hline Planting patterns & $\begin{array}{l}\text { Harvested plant } \\
\text { population }(\%) *\end{array}$ & $\begin{array}{c}\text { Number of pods } \\
\text { per plant }\end{array}$ & $\begin{array}{c}\begin{array}{c}\text { Weight of } 100 \text { seeds } \\
(\mathrm{g})\end{array} \\
\end{array}$ & $\begin{array}{l}\text { Yield } \\
\text { (t/ha) }\end{array}$ \\
\hline \multicolumn{5}{|l|}{ Semanding } \\
\hline Argomulyo monoculture & $100.0 \mathrm{a}$ & $46.4 \mathrm{ab}$ & $13.1 \mathrm{~b}$ & $2.430 \mathrm{a}$ \\
\hline Dena 1 monoculture & $98.7 \mathrm{a}$ & $52.5 \mathrm{a}$ & $12.7 \mathrm{bc}$ & $1.873 \mathrm{~b}$ \\
\hline Dega 1 monoculture & $98.0 \mathrm{a}$ & $49.4 \mathrm{a}$ & $16.7 \mathrm{a}$ & $1.419 \mathrm{c}$ \\
\hline Maize NK 212 + Argomulyo & $73.4 \mathrm{~b}$ & $39.2 \mathrm{bc}$ & $13.4 \mathrm{~b}$ & $1.447 \mathrm{~g}$ \\
\hline Maize NK 212 + Dena 1 & $74.1 \mathrm{~b}$ & $47.3 \mathrm{ab}$ & $13.4 \mathrm{~b}$ & $1.017 \mathrm{~cd}$ \\
\hline Maize NK 212 + Dega 1 & $72.3 \mathrm{~b}$ & $46.1 \mathrm{ab}$ & $17.3 \mathrm{a}$ & $0.820 \mathrm{~d}$ \\
\hline \multicolumn{5}{|l|}{ Merakurak } \\
\hline Argomulyo monoculture & $99.2 \mathrm{a}$ & $51.4 \mathrm{a}$ & $10.7 \mathrm{c}$ & $2.280 \mathrm{ab}$ \\
\hline Dena 1 monoculture & $100.0 \mathrm{a}$ & $46.0 \mathrm{ab}$ & $11.7 \mathrm{bc}$ & $2.160 \mathrm{ab}$ \\
\hline Dega 1 monoculture & $95.0 \mathrm{a}$ & $40.3 \mathrm{bc}$ & $16.7 \mathrm{a}$ & $2.280 \mathrm{ab}$ \\
\hline Maize NK 212 + Argomulyo & $74.9 \mathrm{~b}$ & $32.3 \mathrm{c}$ & $11.3 \mathrm{bc}$ & $1.277 \mathrm{~cd}$ \\
\hline Maize NK 212 + Dena 1 & $76.1 \mathrm{~b}$ & $39.3 \mathrm{bc}$ & $11.7 \mathrm{bc}$ & $1.203 \mathrm{~cd}$ \\
\hline Maize NK 212 & $74.6 \mathrm{~b}$ & $51.3 \mathrm{a}$ & $18.1 \mathrm{a}$ & $1.273 \mathrm{~cd}$ \\
\hline
\end{tabular}

Notes: Values in the same column that followed by the same letters show no significant difference at DMRT 5\%. ${ }^{*}$ Population of $100 \%$ soybean crops with plant spacing of $40 \mathrm{~cm}$ x $15 \mathrm{~cm}$, 2 seeds per-hill was 333,333 crops ha-1

Soybean intercropping with maize has a potency to be developed in production center of maize on drylandupland. Soybean intercropping with maize in double row with plant spacing of $(40 \times 20) \mathrm{cm} \times 200 \mathrm{~cm}$ on DLDC of Tuban District was able to produce maize seeds which were not different from maize monoculture. The intercropping also could increase LER value to 1.48-1.69. The total benefits of soybean intercropping with maize in Semanding and Merakurak could reach IDR 19.1 million and IDR 25.5 million $\mathrm{ha}^{-1}$, respectively, meanwhile, the total benefits from maize monoculture reached IDR 13.9 million and IDR 24.5 million ha ${ }^{-1}$, respectively. Dena 1 intercropping with maize was able to provide higher benefit, economic feasibility, as well as land-use efficiency than Argomulyo and Dega 1, even though in intercropping with maize, Dega 1 has the strongest competitiveness and Argomulyo has the higher soybean yield.

\section{ACKNOWLEDGEMENTS}

We would like to thank the Indonesian Ministry of Agriculture through the Indonesian Agency for Agricultural Research and Development (IAARD) for financial and research facility support for this study,

\section{REFERENCES}

Abdurachman A, Mulyani A, Irawan. 2013. Sumber daya lahan untuk kedelai di Indonesia. In: Sumarno, Suyamto, Widjono A, Hermanto, Kasim H (eds). Kedelai Teknik Produksi dan Pengembangan. Badan Penelitian dan Pengembangan Pertanian, Pusat Penelitian dan Pengembangan Tanaman Pangan, Bogor. [Indonesian]

Addo-Quaye AA, Darkwa AA, Ocloo GK 2011. Yield and productivity of component crops in a maize-soybean intercropping system as affected 
by time of planting and spatial arrangement. ARPN J Agric Biol Sci 6: 50-57.

Amegnaglo CJ. 2018. Determinants of maize farmers' performance in Benin, West Africa. Kasetsart J Soc Sci. DOI: 10.1016/j.kjss.2018.02.011

Ankidawa BA, Vanke I. 2018. Water requirement for maize production in Lake Geriyo irrigation scheme Yola, Adamawa State, Northeastern Nigeria. Noble Intl J Sci Res 2 (8): 49-59.

Belel MD, Halim RA, Rafii MY, Saud HM. 2014. Intercropping of corn with some selected legumes for improved forage production: A Review. J Agric Sci 6 (3): 48-62.

Bi Tra S, Doubi, Kouadio IK, Kouakou LK, Kouamé KK, Jean-Pierre B, Bi Irié AZ. 2016. Existing competitive indices in the intercropping system of Manihot esculenta Crantz and Lagenaria siceraria (Molina) Standley. J Plant Interact 11 (1): 178-185.

Boote JR, Stansell, Schuber AM, Stone JF. 1982. Irrigation, water use and water relations. In: Patte HE, Young CT (eds). Peanut Science and Technology. APPRES, Texas, USA.

Chuanyan Z, Zhongren N. 2007. Estimating water needs of maize (Zea mays L.) using the dual crop coefficient method in the arid region of Northwestern China. Afr J Agric Res 2 (7): 325-333.

Du JB, Han TF, Gai JY, Yong TW, Sun X, Wang XC, Yang F, Liu J, Su K, Liu WG, Yang WY. 2018. Maize-soybean strip intercropping: Achieved a balance between high productivity and sustainability. J Integr Agric 17 (4): 747-754.

Firdaus M. 2015. Self sufficiency outlook of Indonesia soybean on the era of trade liberalization. J Basic Appl Sci Res 5 (1): 105-110.

Flores-Sanchez D, Pastor A, Lantinga EA, Rossing WAH, Kropff MJ. 2013. Exploring maize-legume intercropping systems in Southwest Mexico. Agroecol Sustain Food Syst 37 (7): 739-761.

Habib A, Affandi R, Siregar MR. 2019. Analysis of the Voerseri business feasibility study (a packaged bird feed from Singapore Cherry). IOSR Agric Vet Sci (IOSR-JAVS) 7 (1): 53-59.

Iletri [Balitkabi]. 2016. Deskripsi varietas unggul aneka kacang dan umbi. Balai Penelitian Tanaman Aneka Kacang dan Umbi, Badan Litbang Pertanian, Jakarta. [Indonesian]

Iqbal N, Hussain S, Ahmed Z, Yang F, Wang X, Liu W, Yong T, Du J, Shu K, Yang W, Liu J. 2019. Comparative analysis of maize-soybean strip intercropping systems: A Review. Plant Prod Sci 22 (2): 131 142 .

Istriningsih, Dewi YA. 2015. Performance of soybean's farmer field school-integrated crop management in Central Java and West Nusa Tenggara Provinces, Indonesia. Asian J Agric Develop 12 (2): 33-44.

Du JB, Han TF, GAI JY, Yong CY, Sun TW, Wang XC, Yang F, Liu J, Shu K, Liu WG, Yang WY. 2018. Maize-soybean strip intercropping: Achieved a balance between high productivity and sustainability. J Integr Agric 17 (4): 747-754.

Kornher L. 2018. Maize markets in Eastern and Southern Africa (ESA) in the context of climate change. The State of Agricultural Commodity Markets (SOCO) 2018: Background paper. FAO, Rome

Liang J, He Z, Shi W. 2020. Cotton/mungbean intercropping improves crop productivity, water use efficiency, nitrogen uptake, and economic benefits in the arid area of Northwest China. Agric Water Manag 240: 1-13.

Lithourgidis AS, Dordas CA, Damalas CA, Vlachostergios DN. 2011 Annual intercrops: An alternative pathway for sustainable agriculture. Aust J Crop Sci 5 (4): 396-410.

Liu X, Rahman T, Song C, Su B, Yang F, Yong T, Wu Y, Zhang C, Yang W. 2017. Changes in light environment, morphology, growth and yield of soybean in maize-soybean intercropping systems. Field Crops Res 200: 38-46.

Liu X, Rahman T, Song C, Yang F, Su B, Cui L, Bu W, Yang W. 2018. Relationships among light distribution, radiation use efficiency and land equivalent ratio in maize-soybean strip intercropping. Field Crops Res 224: 91-102.
Lv Y, Francis C, Wu P, Chen X, Zhao X. 2014. Maize-soybean intercropping interactions above and below ground. Crop Sci 54: 914922.

Machado S, Petrie S, Rhinehart K, Ramig RE. 2008. Tillage effects on water use and grain yield of winter wheat and green pea in rotation. Agron J 100 (1): 154-162.

Mahmoudi R, Jamshidi K, Pouryousef M. 2013. Evaluation of grain yield of maize (Zea mays L.) and soybean (Glycine max L.) in strip intercropping. Intl J Agron Plant Prod 4: 2388-2392.

Mahallati MN, Koocheki A, Mondani F, Feizi H, Amirmoradi S. 2014. Determination of optimal strip width in strip intercropping of maize (Zea mays L.) and bean (Phaseolus vulgaris L.) in Northeast Iran. J Clean Prod 106 (3): 390-404.

Matusso JMM, Mugwe JN, Mucheru-Muna M. 2013.. Effects of different maize (Zea mays L.)-Soybean (Glycine max (L.) Merrill) intercropping patterns on yields and land equivalent ratio. J Cereals Oil Seed 4: 48-57.

Mulyani A, Priyono A, Agus F. 2013. Chapters 24: Semiarid soils of Eastern Indonesia: Soil classification and land uses. In: Shahid SA, Taha FK, Abdelfattah MA (eds.). Developments in Soil Classification, Land Use Planning and Policy Implications. Springer, Germany

Oseni TO. 2010. Evaluation of sorghum-cowpea intercrop productivity in savanna agroecology using competition indices. J Agr Sci 2 (3): 229234.

Prasanna BM. 2012. Maize in the developing world: Trends, challenges, and opportunities. Proceedings of International Maize Conference. Sulawesi, Indonesia, 22-24 November 2012

Rahman T, Ye L, Liu X, Iqbal N, Du J, Gao R, Liu W, Yang F, Yang W. 2017. Water use efficiency and water distribution response to different planting patterns in maize-soybean relay strip intercropping systems. Exp Agric 53 (2): 1-19.

Riniarsi D. 2016. Outlook komoditas pertanian tanaman pangan, Kedelai, Pusat Data dan Sistem Informasi Pertanian Kementerian Pertanian. http://epublikasi.setjen.pertanian.go.id. [Indonesian]

Statistics Indonesia [BPS]. 2019. Statistik Indonesia, Badan Pusat Statistik Indonesia. http://www.bps.go.id. [Indonesian]

Uddin MKB, Naznin S, Kawochar MA, Choudhury RU, Awal MA. 2014. Productivity of wheat and peanut in intercropping system. J Exp Biosci 5: 19-26.

Xu Z, Li C, Zhang C, Yu Y, Werf W, Zhang F 2020. Intercropping maize and soybean increases efficiency of land and fertilizer nitrogen use; A meta-analysis. Field Crops Res 246: 1-10.

Yang F, Huang S, Gao R, Liu W, Yong T, Wang X, Wu X, Yang W. 2014. Growth of soybean seedlings in relay strip intercropping systems in relation to light quantity and red: far-red ratio. Field Crops Res 155: 245-253.

Yang F, Wang XC, Liao DP, Lu FZ, Gao RC, Liu WG, Yong TW, Wu XL, Du JB, Liu J, Yang WY. 2015. Yield response to different planting geometries in maize-soybean relay strip intercropping systems. Agron J 107 (1): 296-304.

Yazar A, Ali A. 2017. Water harvesting in dry environments. In: Farooq K, Siddique (eds). Innovations in Dryland Agriculture. Springer, Germany.

Yilmaz S, Atak M, Erayman M. 2008. Identification of advantages of maize-legume intercropping over solitary cropping through competition indices in the East Mediterranean Region. Turkish J Agric For 32 (2008): 111-119.

Yin W, Chai Q, Zhao C, Yu A, Fan Z, Hu F, Fan H, Guo Y, Acoulter J. 2020. Water utilization in intercropping: A review. Agric Water Manag 241: 1-13.

Yu Y, Stomph TJ, Makowski D, van der Werf W. 2015. Temporal niche differentiation increases the land equivalent ratio of annual intercrops: A meta-analysis. Field Crops Res 184: 133-144. 